\title{
Respiratory virus infections in travellers
}

\author{
D. A. J. TYRrell \\ M.D., F.R.C.P., F.R.C.Path., F.R.S. \\ Division of Communicable Diseases, Clinical Research Centre, \\ Watford Road, Harrow, Middlesex HAl 3UJ
}

\begin{abstract}
Summary
Respiratory viruses affect travellers, but the main significance of this is probably that it is in this way that the viruses reach new hosts and thus survive as infectious agents.
\end{abstract}

THIS subject is both too large and too small for a short paper. It is too large, in that every respiratory virus infection that man is heir to can afflict travellers of one sort or another. There seems to be no special proneness to such infections in those who travelin contrast to diarrhoeal infections. This is probably because the common viruses of respiratory tract disease are very widely and uniformly distributed, to judge by the fact that antibodies against them are found in roughly the same frequency in children and adults all over the world. Thus we either have to describe all the viruses which affect non-travellers, and say that they affect travellers too, which is to say too much, or else that the infections are no different from those of non-travellers, which is too little. Instead, I think it may be interesting to consider to what extent the viruses are dependent on travellers for their dissemination and survival.

\section{Influenza and travellers}

It was realized that early influenza epidemics apparently came here from the Far East, and although it was suggested that they crossed the oceans and continents in some mysterious way, closer analysis showed that they travelled no faster than the fastest train or boat. Conversely in recent epidemics it has been said that the influenza epidemics did not cross those boundaries where personal traffic is minimal, as between Western and Eastern Europe and between Israel and her neighbours. Thus when a new serotype first seen in the East has been found in Britain it has from time to time been detected first in travellers-off a boat from Pakistan or schoolchildren returning from a holiday in Hong Kong, for example. Once introduced however, the epidemiologist and virologist lose track of the virus-it may pop up later at many places and there may be little clue as to how it spread, but it must in fact have been passed from individual to individual through a chain of contacts forged during ordinary social intercourse. I was in the Soviet Union recently and there in Leningrad I was shown the results of a computer system which was apparently able to predict the occurrence of epidemics of influenza throughout the USSR. The computer was given first the details of the epidemic wave in the first city in which an outbreak was recognized. Data on the number of persons travelling by air and by land to other cities and between them were also available and were fed in, along with details of the population in each city. From these figures the programme computed when the virus would reach other cities and how big the epidemics would be and certainly the predictions seemed quite close to the events seen. This suggests that in that country the virus spreads in a rather leap-froge fashion around the country in long range transport and then spreads out from each city centre into the surrounding towns and rural areas. I suspect that in Britain our traffic patterns are too complicated and too little known to be used as a basis of such predictions, and in any case the spread may well occur through rural areas and small towns.

\section{Common colds in travellers to and from isolated communities}

There are scattered references in the literature to colds and other respiratory infections in isolated communities and these have recently been reviewed by Holmes and Allen (1973) together with more recent work in which we have studied in particular the islanders of Tristan da Cunha, and groups of scientists isolated in Antarctic research stations. The classic observation on this type of remote community was by Paul and Freese (1933) who studied the island of Spitzbergen and showed that colds died out during the winter and reappeared in the spring when the weather got warmer, the ice broke up and then within a day or so of the first ship arriving a new cold outbreak occurred.

Allen (1973) has shown that in Antarctic stations the frequency of colds is very low during isolation, but once the relief ship arrives and there is interchange and movement of staff again, the frequency of colds rises to a figure which is very similar to that 
which is seen in urban areas. The men in isolation are clearly susceptible since they can be artificially infected with common cold viruses (Holmes et al., 1971). However, the virus cannot persist in individuals who become immune so it must transfer to other susceptibles or die out, so it needs travellers if it is to survive.

There are roughly ten times as many people on Tristan da Cunha as on an Antarctic base, roughly 200 as compared with twenty, but this is still not enough to allow the virus to survive. Over a period of years it was observed that epidemics followed the arrival of ships, and it was noticed on some occasions that relatively brief contact indoors was all that was needed to transfer the infection to an islander and initiate an epidemic (Shibli et al., 1971). When the islanders travelled first to South Africa and then to Britain they had frequent infections, but this was apparently due to the fact that they lacked antibodies to viruses such as parainfluenza virus which are commonly encountered over here, rather than to the travelling itself (Tyrrell, 1967). In one recent study Antarctic personnel developed colds after a long period of isolation which suggests that it was latent in one of them, or possibly survived in the environment-this one documented case of a possible latent infection has to be contrasted now with the numerous examples of epidemics begun by visitors from outside the community. It thus seems likely that in the crowded communities in which most of us live these infections, like influenza, are virtually entirely spread by personal contact with other subjects as part of normal social intercourse.

\section{Amount and conditions of travel}

Mathematical models of epidemics show that an important factor in the occurrence and intensity of epidemics is bound to be the frequency with which an infected person encounters and thus infects other people (e.g. Hammond and Tyrrell, 1971). Thus travelling can be important not merely because it introduces a virus into a new community, but also if we include local travelling in our definition because it increases the number of transfers of infection within a community. In a rural community a sub- stantial proportion of all colds was apparently caugh at home or in the school (Lidwell and Sommerville 1951); but in communities in which public transport such as trains and buses are much used it is likel $\overline{\bar{p}}$. that many infections are transferred there althougt there is no detailed study of the subject. There is goos evidence that colds are transferred more frequentlys. in crowded homes than in uncrowded, and one woul imagine that by improving the standard of ventilas tion, and avoiding packing the passengers too close together it should be possible to reduce the trans mission of respiratory viruses, but at the moment there are no data which would express in terms usefun to engineers the sort of standards they should aim a⿳⺈ - probably the most recent efforts to work on this problem were those of the Air Hygiene Unit in ther last war. At the other extreme the filtered and puris fied air in nuclear submarines and aircraft, which i尺 turned over rapidly, is probably much safer than theo average train, although in space capsules large airts borne droplets may remain suspended in zero gravit? when they would be eliminated rapidly in normat gravity, and this might increase the risks.

\section{References}

Allen, T.R. (1973) Common colds in Antarctica. Journato Hygiene. Cambridge, 71, 649.

HammonD, B.J. \& TYRRELl, D.A.J. (1971) A mathemateado model of common cold epidemics on Tristan da Cun Journal of Hygiene. Cambridge, 69, 423.

Holmes, M.J. \& Allen, T.R. (1973) Viral respiratory diseăse in isolated communities: a review. British Antarctic Surve Bulletin, 35, 23.

Holmes, M.J., Allen, T.R., Bradburne, A.F. \& Stott, E.J⿸户 (1971) Studies of respiratory viruses in personnel at a足 Antarctic base. Journal of Hygiene. Cambridge, 69, $187 \AA$

LiDWELL, O.M. \& Sommerville, T. (1951) Observations on the incidence and distribution of the common cold in a rura community during 1948 and 1949. Journal of Hygiene? Cambridge, 49, 365 .

PAUl, J. \& FreEse, H.L. (1933) An epidemiological an bacteriological study of the 'common cold' in an isolated. Arctic community (Spitzbergen). American Journal of Hygiene, 17, 517.

Shibli, M., Gooch, S., Lewis, H.E. \& Tyrrell, D.A.Jo (1971) Common colds on Tristan da Cunha. Journal of. Hygiene. Cambridge, 69, 255.

TYRRELL, D.A.J. (1967) Serological studies on infections by respiratory viruses of the inhabitants of Tristan da Cunha. Journal of Hygiene. Cambridge, 65, 327. 